\title{
THE IMPLEMENTATION OF CUSTOMARY VALUES ON THE ADMINISTRATION OF GOVERNANCE: A STUDY ON THE VILLAGE GOVERNANCE BASED ON LOCAL WISDOM AT NAGARI KAPAU, AGAM REGENCY OF WEST SUMATRA, INDONESIA
}

\author{
Malau Hasbullah* \\ Doctoral Program of Administration Science, Faculty of Administrative Science, \\ University of Brawijaya, Malang, Indonesia \\ Supriyono Bambang, Hakim Abdul, Muluk M.R. Khairul \\ Faculty of Administrative Science, University of Brawijaya, Malang, Indonesia \\ *E-mail: hasbullahmalau@fis.unp.ac.id
}

\begin{abstract}
Changing in governance practices from centralized to decentralize and shifting from uniformity to diversity in village governance do not necessarily mean customary values that are owned and maintained can be used in the administration of customary (adat) village governance. The problem of the customary village governance arises from the uniformity of villages, the lack of recognition of customary values and the number of customary villages that have been declared during the New Order government. However, the issuance of Law No. 6 of 2014 concerning villages at this time is expected that the customary values can be accommodated to strengthen the course of customary village governance. This study aims to describe and analyze the application of traditional values (local wisdom) used in the administration of Nagari Kapau Government. This study used a qualitative approach whose data collection methods were in the form of in-depth interviews, observation and data triangulation that was carried out to increase credibility. The results of the study revealed that the uniformity of villages in the New Order era apparently was not able to eliminate the traditional values that are owned directly; even the traditional values were still maintained and used in the practice of governing the Nagari Kapau government in Agam Regency, West Sumatera Province. The customary values (local wisdom) used in the task of organizing governance will be described as follows (1) the Kalarasan Koto Philiang Chaniago is used in the decision-making process of the Minangkabau indigenous people, (2) the Adat Basandi Syarak, Syarak Basandi Kitabullah (ABSSBK) is used as a philosophy live in the Minangkabau Indigenous people, (3) the Penghulu (Ninik Mamak) is used as the Nagari owner in the Minangkabau indigenous people, (4) Wali Nagari (the Head of the Customary Village) is used as the Head of Government in the Minangkabau Indigenous Community, (5) Harta Pusaka (Sako Pusako) is used as a legacy system in the Minangkabau Indigenous people, (6) Suku is used as a condition for the establishment of Nagari in the Minangkabau Indigenous people, (7) Tungku Tigo Sajarangan (the three Sajarangan Stove) and Tali Tigo Sapilin as a pattern of Leadership in Minangkabau Indigenous people.
\end{abstract}

\section{KEY WORDS}

Decentralization, local wisdom, government of Nagari, Minangkabau.

The discourse of strengthening local wisdom is increasingly emerging on the administration of governance in Indonesia. It happens in order to overcome shifts in cultural and religious values and to address people's daily problems (Suryono, 2012). The implementation of local wisdom-based governance begins with the debate over the decentralization model on regional government ((Blackwell \& Colmenar, 1999). Dimaggio and Powell (1983) (in Painter and Peters, 2010) revealed that changes in the administrative traditions of a country can occur as it is planned or it happened by itself. Changes in the format of administration adopted by a country could be done in three ways: coercion from external institutions, specifically donor agencies, copying or imitating the administration of 
other countries, making internal changes intentionally through the benchmarking process and best practice. The implementation of decentralization and autonomy is not only a challenge, but also it is a part of public administration's role. Utomo (2012) argued that public administration is not only just a media, tool, implementer of autonomy or decentralization, but also it is as an actor and even it takes a role in the implementation of autonomy/ decentralization.

The counter-attitude towards decentralization emerged during the reform era because of economic interests competition in regions in order to build continuously and strengthen its power in that area. The shift of centralization to decentralization has resulted changes in the model, form, system, pattern and form of governance in Indonesia and it has naturally led to regional redistricring. Nevertheless, the meaning of pemekaran used by the Indonesian people is confusing since the term pemekaran here does not mean to grow bigger as it is compared to the blossoming of flowers. If the term pemekaran is drawn into the regional context, the meaning should be the expansion of size of an area, yet the reality that happens is just the opposite. Pemekaran means the divide of an area or a reduction of an area from its origin. Instead, the expansion literally happens on the regional government, both provincial, district and city, which has an impact on increasing the position and apparatus of the region.

Although there are many contra related to decentralization, there are many public administration practitioners who support the implementation of decentralized governance based on local wisdom as overcoming various kinds of regional problems needs particular strategy based on the characteristic of each region. It can be implemented by creating local wisdom-based governance that is able to overcome regional problems, specifically on custom issues.

The emergence of local wisdom is expected from traditional villages or village autonomy, as a legal community unit that has the authority to manage and do self-manage. It means that the village has autonomous rights that are different from the formal autonomy belonging to the provincial, district and city governments. However, the autonomy is limited to the origin and customs that has been applied in society. The form is structured into informal and formal government systems before and after the Republic of Indonesia is established. Therefore, the local wisdom is better known as the "adat village or adat government". An interesting study conducted by F. von Benda-Beckmann \& K. Von BendaBeckmann (2013) explained deeply the formation of village government during the government regime at that time that always related to the actual findings that occur in villages in West Sumatera. Joeniarto (1992) mentioned that there were several regions in Indonesia that also had local wisdom-based governance system, such as Java, Madura, and Bali that is called desa; in Sumatera it is called Kampung, Huta, Nagari; in Kalimantan it is called Tumenggungan; in Sulawesi there are Wanua, District, Pakasoan; in West Nusa Tenggara it is called Banjar, Lomblan; in East Nusa Tenggara it is called Mapoa, Laraingu, Kenaitan, Keftaran, Kedatoan, Kedaluan; and in Maluku and in Papua it is called Goa, Koana and Nagari. Many terms are used in order to understand local wisdom or custom-based government, such as local wisdom, local genuine, local genius, local knowledge.

Based on the issuance of Law No. 6 of 2014 concerning Villages and Article 18 on Village Authority, the village administration has an authority that covers the village governance, development implementation, community development, and community empowerment based on community initiatives, rights of the origin, and the customs (adatistiadat) of the village. since the implementation of the village administration system during the New Order era, the traditional institutions supporting Nagari in the Minang realm have been marginalized so that they only play a role in the ceremonial cultural sphere. Meanwhile, the policy to revitalize Nagari was carried out by combining formal government arrangements with the adat system. The government system was formalized by the formation of an executive institution (Wali Nagari and its apparatus) and the legislature (the Nagari Children's Representative Body), while the adat system was formed by the formation of the Nagari Customary Institution (LAN) and the custom (Adat) and Syarak Nagari Consultative Body (BMASN) which adopted the custom (adat) order. 
Combining two different systems according to some parties is the best "middle way" to revive local wisdom in the midst of the current modern government system. The synergy of customary values (local wisdom) and the values of regional autonomy (national wisdom) which is different provides opportunities for tugging each other, even it results conflict among certain elites and co-optimization in the administration of the Nagari Government. According to Asnan (2006) the Government system (Nagari) as local wisdom, had been carried out by the Minangkabau indigenous people before the Dutch colonialism and the Republic Indonesia was formed.

According to a study conducted by Nurdin (2006) regarding Nagari Malalo that there was something contested for certain political interests, where a group of people used Nagari as a tool or a media for the sake of their power. This is the focus of attention of researchers in conducting research on the implementation of traditional values (local wisdom) that are used in the administration of the Nagari Kapau Government, especially the manifestation of traditional values (local wisdom).

\section{LITERATURE REVIEW}

The implementation of decentralization in a unitary state means the transfer of power from the central government as a national public body to the regional government as a local public body. Grindle (2007), viewed the phenomenon of decentralization in the economic, political and administrative contexts as something that could not be separated from public policy reforms which were logical consequences in realizing good governance. Thus Smith (1985) asserted that decentralization was a political choice that emphasized in achieving political goals.

Regarding decentralization, Muluk (2009) explained the three main perspectives, approaches and theoretical levels of decentralization. The first approach is liberal democracy that considers decentralization is a means of realizing democratization at two levels, the national and regional levels. On the national level, it can make a positive contribution to the development of national democracy. The benefits of decentralization on the national level are the creation of political education, training in political leadership and the creation of stable national politics. While, the benefits of decentralization on the local (regional) level are the creation of political equality, high responsiveness to region, the emergence of accountability and accessibility and the creation of spread of power. The second approach is public choice theory, decentralization using the approach of economists. As Stoker (1991) stated that public choice theory considers decentralization as an important medium for enhancing personal welfare through public choice. The third approach is the Marxist approach, a different view firmly states that decentralization results in a state at the local level. Decentralization is viewed as an object of the dialectics of relations between government structures, and even they assume that decentralization will not be able to create democratization at the local level, due to economic, political and ecological obstacles.

Providing the widest possible autonomy on the selection of the autonomy system in a unitary state is important. According to Busrizalti (2013), it is necessary to do a number of basic things, such as encouraging efficiency and effectiveness of regulation (regelen) and administration (bestuuren) of government. Having the authority to self-regulate in certain areas of government which are the affairs of regional households' enables the creation of rules efficiently and quickly. Similarly, the administration of government will be more efficient and effective too.

In Public Administration literature, the process of internalizing local wisdom in the bureaucracy of local government such as the Nagari Government as the lowest government is a form of administrative reform. The concept of administrative reform was initiated from the development of the concepts of decentralization and regional autonomy in the constitutional system. It has become a necessity, as determined by the founders of this country in the 1945 Constitution. It is made by considering various aspects, both on aspects of the heterogeneity of ethnic, religious, cultural backgrounds and the vast territory of the country. Thus, the choice of a decentralized government system is the most appropriate choice to apply. The 
role of administrative science in improving the level of validity and relevance of its policies conceptually is to improve the practice of decentralization for the better future. This is in accordance with the empirical conditions regarding the development of public administration and decentralization practices, especially village governance based on traditional values (local wisdom).

If it is seen from the tendency of improving development administration, the governance is oriented to the integration of local self-government with self-governing community in the formation of customary village governance, as stated by Fadli et al., (2013) that the Republic of Indonesia is divided into provinces, districts/city and village. Village, as a form of traditional autonomy in the framework of self-governing community, is called "original autonomy" while the position of local self-government is a form of "modern autonomy" that is under of the nation state.

However, customary values (local wisdom) continue to base themselves on public administration and state administrative analysis tools so that the local government that is based on local knowledge in scientific discipline cannot be separated from state administration. The development of administrative on the problem of the aforementioned local values at this time has been strengthened by a shift in the concept of "government" to governance ". It means that it has developed the term "governance" which has a different application meaning from "government" within the implementation of local government. If the government formally refers to state institutions, it is characterized by a monopoly of power in the making and its implementation authoritatively, while governance shows changes in the meaning of government which refers not solely on the monopoly of government power, but it involves all elements (stakeholders) both internal bureaucracy and external bureaucracy public, the people (society) and the business world (private sector) (Sjamsuddin, 2007).

In the historical dynamics of Nagari especially after the transition from centralization to decentralized government, the Minangkabau people see a way to return to indigenous culture with all challenges in the middle of social change (Vel \& Bedner, 2015). They see a new opportunity to return to the past, so that the structure of government becomes the classic Nagari. Nagari is a traditional community unit that is still alive and the community uses traditional values (local wisdom) to govern Nagari in daily life. Thus, the Nagari government in West Sumatera as a customary village is an indigenous community unit that is not formed by the State but it has been formed by the community through a long process that is approximately for tens or even hundreds of years ago. For instance, Nagari Kapau is a luhak nagari (original Nagari) whose administration of Nagari is still based on custom (adat), and it is not a village that is formed by the Regency and City Governments (Azwar et al., 2018).

Thus, decentralization is a choice, particularly the choice of returning to Nagari as a symbol of Minangkabau community identity. The Nagari Government that is coveted by the Minang community is a cultural heritage. Besides, the Nagari government is also the representation to accommodate people from cultural aspects that are in accordance with the cultural characteristics of the people. In addition, it also images themselves as a Minang tribe living in West Sumatera Province.

\section{METHODS OF RESEARCH}

This study used a qualitative approach, given its aim to uncover what is happening in empirical reality. This research observed more and explored the behavior of the objects studied, so that it needed to find, understand, explain and obtain social phenomena that was related to custom-based village governance within the administration of Nagari Kapau government in Agam Regency, West Sumatera Province.

Lincon and Guba (1985) stated that qualitative research (naturalistic) is a method of research that is intended to understand actuality, social reality, and the perception of the human being. This approach could reveal real events on the field and it also could show the hidden values, including describing and interpreting an event or phenomenon. Thus, this 
approach is able to capture the essence of human emotions, feelings, and perceptions in personal contexts.

The reasons why this study employed qualitative approach are the interpretation of traditional values (local wisdom), the use of traditional values (local wisdom) and the synergy of values with Law No. 6 of 2014 in organizing the Nagari government can strengthen the practice of government. This research was conducted in Nagari Kapau as the lowest government in Tilatang Kamang District, Agam Regency, West Sumatera Province. Nagari Kapau was chosen as the object of the study as it is based on the consideration that Nagari Kapau is Nagari Luhak (Original Nagari) which has very strong traditional characteristics such as strong blood ties genealogically. Even though they have lived outside of Kapau Nagari for example in Java, Kalimantan and Overseas (Singapore and Europe) but they still have rights and obligations as children of Nagari Kapau.

Determining the focus of the study aims to limit the study (field of inquiry) and to meet the inclusion-exclusion criteria for new information obtained in the field (Moleong, 2010). The customary values (local wisdom) that are used in the administration of Nagari Government are (1) Genealogis Kalarasan Adat Koto Philiang as a Decision Making Process in the Minangkabau Indigenous Peoples in Nagari Kapau, (2) Genealogis Adat Basandi Syarak, Syarak Basandi Kitabullah (ABSSBK) as an indigenous philosophy in Nagari Kapau, (3) Genealogis Penghulu (Ninik Mamak) as Nagari Owner in the Minangkabau Indigenous People in Nagari Kapau, (4) Genealogis Wali Nagari as Head of Government of the Minangkabau Indigenous Peoples in Nagari Kapau, (5) Genealogis Sako Pusako in the Minangkabau Indigenous Peoples' inheritage in Nagari Kapau, (6) Genealogis Suku in the Minangkabau Indigenous Peoples as a condition for the establishment of Nagari in Nagari Kapau, (7) Genealogis Tungku Tigo Sajarangan and Tali Tigo Sapilin as Leadership in the Minangkabau Indigenous Peoples in Nagari Kapau.

The informants involved in this study were Nagari and his staff (secretaries of Nagari, Kaur Nagari, and Wali Jorong Nagari) while the indigenous people of Nagari Kapau provided (Penghulu / Ninik Mamak) of 9 tribes of Nagari Kapau, Penghulu (Ninik Mamak) Jorong, Pucuk Bulek 6 (six Tribes) as executors of traditional Values (local wisdom). The interactive data analysis used by researchers refers to Miles, Huberman and Saldana (2014), which is to analyze the data obtained in the field and to move back and forth continuously throughout the research. Data collection methods in the form of in-depth interviews, observation and data triangulation were carried out to increase credibility.

\section{RESULTS AND DISCUSSION}

Decentralization and regional autonomy became the beginning of recognition of the customary village governance. In the context of implementing the customary (adat)-based villages, the customary villages apply customary values as a basis in implementing the village governance. The Customary village governance that adopts traditional values starts with Law no. 22 of 1999 and Law No. 32 of 2004 as a part to revive Nagari. After that, the West Sumatera Province Regulation No. 9 of 2000 and Number 2 of 2007 concerning the Principal Provisions of the Nagari Government were issued. Meanwhile, Nagari Kapau is based on Agam District Regulation No. 31 of 2001 concerning the Government of Nagari. The reuse of traditional values owned and maintained by the indigenous people of Nagari Kapau in practice is described as follows:

1. Genealogis Kalarasan Adat Koto Philiang in the Decision Making Process of the Minangkabau Indigenous People.

The customary values of Kalarasan Adat Koto Piliang are used in the decision making process in the administration of governance in Nagari Kapau, Agam Regency, West Sumatra Province. The use of the Kalarasan Koto Philiang traditional value is closely related to the history of the Minangkabau central figure, Datuk Ketumunggungan. He used the value during the process of decision making and he also applied it in the practice of governance. The decision-making process at Nagari Kapau is based on the customary values of Kelarasan Koto Piliang through a mechanism and the procedure used is top-down. This means that all 
decisions must have guidelines from the fatwa or decree of the higher ranking head (penghulu pucuk). The example from the implementation of Nagari Government is when the source of the problem comes from custom, then Datuk Bandaro takes the decision. However, if the problem comes from syarak (religion) then Datuak Mangkudun will make the decision. The decision making according to the customary hierarchy system in the customary proverb is explained as follows: "Bajanjang naik bertangga turun" (Bajanjang rises down stairs) and the highest headman is called as penghulu pucuk. Then, penghulu pucuk in Nagari Kapau are (1) Datuak Bandaro as the headman of the Jambak Gadang tribe (2) Datuak Mangkudun, the headman of the Malay tribe (3) Datuak Palimo, the headman of the Koto tribe (4) Datuak Tandilangik, the headman of the Guci and Pili tribe (5) the Datuak Panduko Basa, the headman of Tanjuang, Pisang and Simabua (6) Datuak Indo marajo, the headman of Jambak Kacik tribe.

If anyone disagrees with the decision given, they will be given a penalty. The decision of the headman (Ninik Mamak) is a decree and it must be implemented, even though the decision was only taken unilaterally by the headman without being discussed with the Nagari community and their people as a whole.

Thus, if there is a problem, Penghulu Pucuk will discuss it first. That is the way how the customary values are implemented in Nagari Kapau. The trial is held if there has been already a complaint or offense that must be decided, concerning the Nagari community. However, if the issue is only administrative thing, Wali Nagari (Kepala Desa Adat or Head of the Customary Village) and his staff can make a decision without consulting with Penghulu (Ninik Mamak). It happens this way as Wali Nagari and the employees who work in the Nagari Government are their relatives. Therefore, the decision making at Nagari Kapau is based on Koto Philiang traditional values, where decisions are made by the highest headman or top down and the Nagari people only follow the decision.

Based on the explanation above, it shows that Nagari Kapau has its own Government as the main dominant social unit. This makes the characteristic of the Minangkabau people Nagari is an autonomous customary law community unit, and it is a mini republic with clear territories for its members (Ibrahim, 2009).

2. Genealogis Adat Basandi Syarak, Syarak Basandi Kitabullah (ABSSBK) as the customary philosophy.

The philosophy of social life of the Minangkabau people or the philosophy of Minangkabau customary life is called "Adat Basandi Syara 'Syara' Basandi Kitabullah" which means syara 'mangato adat mamakai or within the life order that has been adhered to for generations and it always upholds the religion value and the established customs in Nagari. This philosophy has become a culture that is adhered to and it has been used for generations by the people of Nagari Kapau.

The values of the philosophy of "Adat Basandi Syara 'Syara' Basandi Kitabullah" are used in the administration of the Nagari Government such as; (1) the requirement that has to be fulfilled in order to be a candidate for Wali Nagari (Head of the Customary Village) is Muslim and it has been institutionalized in the rule of the Nagari Government in determining the Wali Nagari (Head of the Customary Village); (2) in Nagari's tribe, those who want to become a child of Nagari Kapau must be a Muslim. Afterward, he or she will be recognized by the headman as his child; (3) the religion in Nagari Kapau is only Islam. This becomes the Minang cultural value and if there are Minang tribal children who are not Muslim then they will not be recognized in the tribe and its people; (4) in setting Nagari regulations, Adat Basandi Syara ', Syara' Basandi Kitabullah becomes the reference in formulating the Nagari Government regulation; (5) establishing Nagari Kapau as anti-immoral Nagari; (6) fostering the improvement of the religion understanding for the younger generation in the form of AlQur'an hafiz activities, training to handle the corpse and youth of the mosque, for each child of Nagari Kapau.

The Nan Duo Puluah Law shows that legal sources in Minangkabau are based on three principles namely the law of Kitabullah (the Book of God), the ijtihad law and the testimony of a figure for instance Datuk Seri Maharaja Nan Banego-Nego (Datuk Perpatih Nan Sabatang's younger brother). The people are asked to swear to continue using the three 
sources of law as a legal basis for generations and it must not be changed forever. Since then the old customary system has been renewed by socializing it into the existing Nagari(Ibrahim, 2009).

3. Genealogis Penghulu (Ninik Mamak) As Nagari Owner of the Minangkabau Indigenous People.

The genealogical value of the Penghulu as the owner of Nagari in the Minangkabau indigenous people, is still used in the administration of the Nagari Government. Although there was a change due to the imperialism of the Netherlands, yet afterward the uniformity of villages is applied in the New Order era and the era of reform, as well as the current regional autonomy. However, Nagari Kapau continued to use its traditional values such as Penghulu as the owner of Nagari.

Then, the Penghulu program in order to strengthen the implementation of the Nagari Government is: (1) coordination meetings with the group of the Penghulu VI Suku (KAN VI Suku) once in every 3 months, (2) facilitating learning and fostering Nagari customary issues in Jorong (sub village) sharing, (3) a joint commitment between the government and KAN VI Suku with the Nagari Deliberation Board (BAMUS or Badan musyawarah Nagari), (4) generating the enthusiasm and love toward the indigenous culture of Nagari, (5) realizing the young generation who are well-mannered and excellent.

4. Genealogis Wali Nagari (Head of the Customary Village) As the Head of Government of the Minangkabau indigenous people.

Wali Nagari as the Head of Government of the Minangkabau Indigenous People is also used in Nagari Kapau as the lowest government. Wali Nagari was chosen in several steps starting from the initial process of nomination, in which Penghulu submitted the names of the candidates. After that, he was directly elected by Nagari residents. In this way, the process of recruiting candidates for Wali Nagari is executed in a planned, directed, structured selection, then they are appreciated through positive imagery.

However, currently there are changes in the election of Wali Nagari due to adjustments to the prevailing political environment conditions, especially the role and interests of the National and Regional governments in determining the Wali Nagari criteria. This refers to Government Regulation Number 72 on Villages in 2005, specifically refers to Agam District Regulation number 12 of 2007. In article 18 of Regional Regulation 12/2007 it is stated that the duties of Wali Nagari (Head of Customary Villages) are: implementing the duty of Government, Development and society. In order to carry out the duty of the Nagari Government, the Wali Nagari is assisted by the Nagari Apparatus who consists of: Secretary of the Nagari, Head of Government Affairs, Head of Development, Head of Social Affairs, Head of Finance and Assets, Treasurer, Wali Jorong (sub village).

In order to administer the governance, Wali Nagari Kapau has made various breakthroughs in economic, social and development improvement as follows: (1) participating in the management of the Nagari Kapau market in the form of completing market facilities and infrastructure such as; parking lots, waste management, market security and traders' arrangements, (2) establishing Nagari Kapau Children's Educational Assistance Agency, (3) approaching migrants in Jakarta, Bandung, Surabaya, Malaysia, and other Kapau Family Associations, (4) conducting training and supervision of financial institutions in Nagari such as BMT (baitul maal wa tamwil/ sharia microfinance).

Wali Nagari applies the principle of transparent service, he prioritizes satisfaction and accountability in the form of: (1) setting public service standards that contain the type of service, requirement, cost and time. The service standard is informed to the public through leaflets, bulletin board, banner stand, (2) every community that deals with correspondence to the Wali Nagari Office (Head of Customary Village) first requests a letter of introduction (Recommendation) from the Wali Jorong (Head of Dusun), (3) creating a comfortable atmosphere in the provision of services to the community through the arrangement of service rooms, (4) improving the quality of service officers through training, (5) managing and overseeing the discipline of Nagari Devices, (6) socializing government programs through Mosques in each Jorong (sub village).

5. Genealogis Harta Pusaka (Sako Pusako) on the inheritance of the Minangkabau 
Indigenous People.

Property arrangements (pusako harato) in Nagari Kapau include: houses, cleared land, forests, fields, gardens and others. This wealth that is in the Minangkabau Heritage has been formalized in the administration of the Nagari Government in Nagari Kapau, Agam Regency, West Sumatera. The regulation of the inheritance or wealth in the customary government and the arrangement and stipulation is executed by Penghulu Nagari in the Nagari traditional institution, not the Wali Nagari. Wali Nagari only takes care of the administration from the results of the stipulation.

The use of assets that is related to the administration of Nagari Kapau governance has been regulated as follows: (1) land is not permitted to certify, (2) selling land has a customary law stating that the land must be sold among Kapau's fellow, (3) customary letters and its boundaries issued by Penghulu, (4) Nagari Kapau Harta Pusaka (Sako Pusako) such as houses, land, rice fields and fields may not be sold to outsiders. If they sell the land to the residents that are outside of Nagari Kapau, they will receive customary sanctions as stipulated in the charter of the Niniak Mamak Nagari Kapau Indigenous Laws 1912, 1925, 1955, 1997 and 2003, stated that they need to pay debts as stipulated in the charter.

6. Genealogis Suku In the Minangkabau Indigenous People as the requirement for the establishment of Nagari.

One of the requirements for the establishment of Nagari is a tribe which is a Genealogical customary values used in the administration of the Nagari Government. The tribe as one of the Minangkabau traditional inheritance applies autonomously to each Nagari, and the uniqueness of each Nagari is based on the Genealogical tribe of each Nagari. The Minangkabau traditional saying stating that "adat selingka Nagari" (custom is applied around Nagari) as well as "waris salingka Nagari (inheritance is applied around Nagari)". However, the practice of governing Nagari government in a Genealogical tribe in the Minangkabau indigenous people is very closely related to the subject and object of government. The tribe in Nagari is (1) the tribe, the first people to inhabit Nagari, (2) the tribe, the person who founded Nagari, (3) the tribe, through the Penghulu (Ninik Mamak), is the owner of the Nagari, (4) the tribe, Nagari residents.

While Amir (1997) stated that each establishment of a Nagari has four conditions that are expressed in an adat proverb that reads "Nagari kaampek suku, dalam suku babuah paruik, kampong nan batuo, rumah batungganal" (Nagari with four tribes, in fruitful tribes stomach, the old village, and batungganai house). This means that each Nagari established must consist of: (1) having four tribes, (2) each tribe has several stomachs (descendants of mothers), (3) having tribal leaders who will be holders of Nagari Government collectively, (4) batungganai house, which has a head of the people called the head of the family who lives in a house according to the matrilineal system (Takano, 2018).

7. Genealogis Tungku Tigo Sajarangan and Tali Tigo Sapilin As a Model of Leadership pattern in the Minangkabau Indigenous People.

The Tungku Tigo Sajarangan (the Three Sajarangan stove) is used by the Minangkabau indigenous people as a symbol of the three leadership elements in Minangkabau such as the headman or Penghulu (Ninik Mamak), the religious scholar (Alim Ulama) and the Scholar one (Cadiak Pandai). Whereas Tali Tigo Sapilin refers to three bases as a base for Tungku Tigo Sajarangan. The three foundations are customary provisions which are the basis of the Penghulu, religious law or sharak as the authority of the Alim Ulama, and the Law which is the basis or foundation of Cadiak Pandai.

In the era of reform and regional autonomy, referring to LKAAM West Sumatra Decree No. SK-17 / PP / LKAAM-SB / 2003, namely the main tasks and duties of the tungku tigo sajarangan (based on West Sumatra LKAAM SK No. SK-17 / PP / LKAAM-SB / 2003) and their competencies in the knowledge system in Minangkabau: (1) Niniak mamak, is a person who has a role and responsibility in bequeathing customs, order values of politeness and affective behavior in society that is in accordance with customary provisions. A penghulu within the knowledge system in Minangkabau, has a competence and an authority, especially in the aspect of indigenous knowledge, which comes from "raso and the philosophy of "alam takambang jadi guru (experience is the best teacher)". At present time, the function has not optimally showed the results as the community tends to look at the 
exemplary form of the Penghulu element in carrying out customary values consistently. (2) Alim ulama, is a person who has a role in carrying out and giving understanding to the people on the origin of syara 'which comes from the Koran and the Hadith. Alim ulama within the knowledge system in Minangkabau, has the potential and special authority in the aspects of religious knowledge and beliefs (theology) that originate from revelation. The problem that arises at this time is the loss of the authority of some alim ulama in the midst of the community, so that the community can easily take actions that violate religious values. Meanwhile, the personalization of alim ulama does not reflect the values comprehensively. In addition, the personalization of alim ulama sometimes does not reflect its proper value, thereby they loss the trust of the community. (3) Cadiak pandai, is a person who has a competence and an authority in the field of science (cognitive) and laws that originate from nature of thought and logic (rationality).

Thus, referring to the statement of Sirait et al., (1999), the unity of indigenous and tribal peoples refers to the understanding of organic communities that carry out their functions through their governmental organizations as instruments of indigenous people. However, the Unity of indigenous and tribal peoples, both living and dead as explained by Asshiddiqie (2007) as follows. First, the people are still native, the tradition is still practiced, and there is a record of the tradition. Second, the people are still native and the tradition is still practiced but there is no record of the tradition. Third, the people are still native but the tradition is not practiced anymore but there are records or written records related to the tradition which can be re-practiced at any time. Fourth, the people are still native but the tradition is gone and there are no recordings of the tradition. Fifth, the people are no longer native, the tradition has also been lost, and the records are also gone except only in legends that are not written. Sixth, the people are no longer native, the tradition has also disappeared from daily practice but the records are still available and it can be revived at any time. Seventh, the people are no longer native but the tradition is still practiced and the records are also quite adequate. Eighth, the people are no longer native and there is no record of this but the tradition is still alive in practice.

\section{CONCLUSION}

Based on the results of the discussion above, it can be concluded that the customary values used are based on history and their origin and they are applied in accordance with their functions through governance organizations as an instrument of the indigenous people. In this way, referring to local wisdom means that the traditional values in Nagari Kapau are social capital that is used in the administration of the Nagari governance as an adat (customary) governance. While, the customary values (local wisdom) used in the task of organizing governance will be described as follows (1) the Kalarasan Koto Philiang Chaniago

is used in the decision-making process of the Minangkabau indigenous people, (2) the Adat Basandi Syarak, Syarak Basandi Kitabullah (ABSSBK) is used as a philosophy live in the Minangkabau Indigenous people, (3) the Penghulu (Ninik Mamak) is used as the Nagari owner in the Minangkabau indigenous people, (4) Wali Nagari (the Head of the Customary Village) is used as the Head of Government in the Minangkabau Indigenous Community, (5) Harta Pusaka (Sako Pusako) is used as a legacy system in the Minangkabau Indigenous people, (6) Suku is used as a condition for the establishment of Nagari in the Minangkabau Indigenous people, (7) Tungku Tigo Sajarangan (the three Sajarangan Stove) and Tali Tigo Sapilin as a pattern of Leadership in Minangkabau Indigenous people.

\section{REFERENCES}

1. Amir, M. S. (1997). Adat Minangkabau, Tujuan and Pola Hidup Orang Minang. Mutiara Sumber Widya: Jakarta.

2. Asnan, G. (2006). Pemerintahan Sumatera Barat dari VOC hingga Reformasi. Citra Pustaka: Jakarta. 
3. Asshiddiqie, J. (2007). Hak Konstitusional Masyarakat Hukum Adat. Makalah disampaikan dalam Loka-karya Nasional. Jakarta.

4. Azwar, W., Yunus, Y., Muliono., \& Permatasari, Y. (2018). Nagari Minangkabau: The study of Indigenous Institutions in West Sumatra, Indonesia. Jurnal Bina Praja, 10 (2), 231-239. doi: 10.21787/jbp.10.2018.231-239.

5. von Benda-Beckmann (2013). Political and Legal Transformations of an Indonesian Polity: The Nagari from Colonisation to Decentralisation. Cambridge: Cambridge University Press. doi: http://dx.doi.org/10.1017/CBO9781139839082

6. Blackwell, A., \& Colmenar, R. (1999). Transforming policy through local widom. Futures, 31. 487-497.

7. Busrizalti, 2013. Hukum Pemda otonomi daerah and implikasinya, Total Media: Yogyakarta.

8. Fadli. M., Hamidi. J., \& Lutfi, M. (2013). Pembentukan Peraturan Desa Partisipatif (Head To A Good Village Governance). UB Press: Malang

9. Grindle, M. S. (2007). Going Local: Decentralization, Democratization, and the Promise of Good Governance. Princeton University Press. New Jersey, USA.

10. Ibrahim Dt. S, D. (2009). TAMBO Alam Minangkabau, Tatanan Adat Warisan Nenek Moyang Orang Minang. Kristal Multimedia: Bukittinggi.

11. Joeniarto, R (1992). Perkembangan Pemerintahan Lokal. Bumi Aksara: Jakarta.

12. Lincoln, Y. S., \& Guba, E. G. (1985). Naturalistic Inquiry. Beverly Hills.Sage Publications London.

13. Miles, M. B., Huberman, A. M., \& Saldana, J. (2014). Qualitative Data Analysis: A Methods Sourcebook. SAGE Publications Inc. Singapore.

14. Moleong, L. J. (2010). Metodologi Penelitian Kualitatif. Edisi Revisi. PT Remaja Rosdakarya. Bandung.

15. Muluk, M. R. K. (2009). Peta Konsep Desentralisasi and Pemerintahan Daerah. ITS Press bekerjasama dengan Lembaga Penerbitan and Dokumentasi FIA - Unibraw. Surabaya.

16. Nurdin, B. V. (2006). Nagari Malalo: Studi Tentang Kontestasi and Hubungan Kekuasaan, Disertasi Pascasarjana UI. Jakarta.

17. Painter, M., \& Peters, B. G. (2010). Tradition and Public Administration. Palgrave Macmillan. Hampshire.

18. Peraturan Daerah Sumatera Barat Nomor 9 Tahun 2000 tentang Ketentuan Pokok Pemerintahan Nagari.

19. Peraturan Daerah Kabupten Agam Nomor 31 Tahun 2001 tentang Pemerintahan Nagari.

20. Peraturan Daerah Sumatera Barat Nomor 2 Tahun 2007 tentang Pokok-Pokok Pemerintahan Nagari.

21. Sirait, M., Fay, C., \& Kusworo, A. (1999). Bagaimana Hak-Hak Masyarakat Hukum Adat dalam Mengelola Sumber Daya Alam Diatur. Southeast Asia Policy Research Working Paper, (24), 1-67.

22. Sjamsuddin, S. (2007). Good Governance. Jurnal Ilmiah Adminitrasi Publik (JIAP), 5 (3).

23. Smith, B. C. (1985). Decentralization: the Territorial Dimension of the State. George Alien \& Unwin. London.

24. Stoker, G. (1991). The Politics of Local Government. Edition 2. MacMillan Education Ltd. London.

25. Suryono, A. (2012). Birokrasi and Kearifan Lokal Indonesia. UB Press. Malang.

26. Takano, S. (2018). Political and Legal Transformation of an Indonesian Polity: The Nagari from Colonization to Decentralization. Book Review: Polar Online. 1-3.

27. Undang-Undang Nomor 22 Tahun 1999 tentang Pemerintahan Daerah.

28. Undang-Undang Nomor 32 Tahun 2004 tentang Pemerintahan Daerah.

29. Undang-Undang Nomor 6 Tahun 2014 tentang Desa.

30. Utomo, W. (2012). Administrasi Publik Baru Indonesia. Pustaka Pelajar: Yogyakarta.

31. Vel, J. A. C., \& Bedner, A. W. (2015). Decentralisation and village governance in Indonesia: the return to the nagari and the 2014 Village Law. The Journal of Legal Pluralism and Unofficial Law, 47(3), 493-507. 